\title{
AC 2010-330: HOW THE CIVIL ENGINEERING BOK2 IS BEING IMPLEMENTED AT THE UNIVERSITY OF ALABAMA
}

\section{Kenneth Fridley, University of Alabama}

Kenneth J. Fridley, PhD, F.ASCE, has been at The University of Alabama since 2003 where he is professor and head of the civil, construction and environmental engineering department. In 2006, he served as an administrative fellow for the office of the executive vice president and provost of the University. He is the 2010 recipient of the T. Morris Hackney Award for Faculty Leadership.

Fridley has gained a variety of experience in structural wood engineering through his studies of the creep-rupture of wood, the vibrations, durability and deflection of wood structures, and the response and protection of wood-frame buildings to natural hazards, such as wind and earthquakes. He has been active in various areas of research and has been awarded numerous externally-funded research grants. In addition, Fridley has more than 70 refereed publications and over 100 conference presentations.

In addition to teaching and research, Fridley is involved in numerous professional activities and organizations. Since 1990, he has been a member of the American Society for Engineering Education. In 2008, he was named a Fellow of the American Society of Civil Engineers and he has held numerous leadership positions in the organization, including vice chair of the BOK committee and chair of the BOK educational fulfillment committee.

Prior to joining the University, Fridley served as the associate dean for research and information technology at the Howard Hughes College of Engineering at the University of Nevada. He also served in various faculty positions at Washington State University, the University of Oklahoma and Purdue University. 


\title{
How the Civil Engineering BOK2 Is Being Implemented at The University of Alabama
}

\begin{abstract}
The second edition of the Civil Engineering Body of Knowledge for the $21^{\text {st }}$ Century (BOK2) is a comprehensive, coordinated list of 24 outcomes which define the knowledge, skills, and attitudes expected of the future civil engineer. The BOK2 outcomes use Bloom's Taxonomy for cognitive develop to help define the levels of achievement expected to be achieved prior to entry into the professional practice of civil engineering, as well as the levels of achievement for each outcome relative to each stage in the engineer's development, from the baccalaureate degree program, to post-baccalaureate formal education, to pre-licensure working experience. This system clearly identifies the role and responsibilities of the civil engineering profession in the technical and professional development of the future engineer and their ultimate achievement of the BOK.
\end{abstract}

As part of a continuing effort, ASCE's Body of Knowledge Educational Fulfillment Committee (BOKEdFC) is examining how programs are responding to the BOK2 and possible ways the BOK2 outcomes may be integrated into civil engineering curricula. Previously, the BOKEdFC examined survey data illustrating how well programs, in their current design, achieve the educational outcomes of both the first and second editions of the civil engineering BOK. Based on the survey data and analysis, the BOKEdFC concluded that several BOK2 outcomes may be "challenging" for many programs to address in today's civil engineering curricula. These include the nine "red outcomes" shown in Figure 2 (i.e., Outcomes 3 - Humanities, 4 - Social Sciences, 10 - Sustainability, 11 - Contemporary Issues \& History, 12 - Risk \& Uncertainty, 17 - Public Policy, 18 - Business \& Public Administration, 19 - Globalization, and 20 Leadership). In addition, the committee identified Outcomes 5 - Material Science and Outcome 24 - Professional \& Ethics as outcomes that may be challenging for programs to fully implement.

The purpose of this paper is to provide a comprehensive analysis of the University of Alabama's civil engineering curriculum with respect to the second edition of the BOK2, or more specifically the BOK2 outcomes associated with the baccalaureate degree since the BOK2 includes outcomes for baccalaureate and post-baccalaureate formal education as well as pre-licensure experience. Specific emphasis is given those BOK2 outcomes that the aforementioned survey data identified as being a challenge for many programs to address within current curricular design. The curriculum, as developed by the faculty, is considered to be BOK2-conforming, in addition to meeting current university graduation and ABET/EAC accreditation requirements.

\section{Introduction}

The first edition of the Civil Engineering Body of Knowledge for the $21^{\text {st }}$ Century ${ }^{1}$ (BOK1) was released in January 2004. Based on various inputs, a second edition of the Civil Engineering Body of Knowledge for the $21^{\text {st }}$ Century $^{2}$ (BOK2) was developed and released in February 2008. The BOK1 has already impacted accreditation criteria and civil engineering curricula. The BOK2, while being more recent and not yet addressed within accreditation criteria, is motivating additional change in some civil engineering curricula. Considering specifically the BOK2, a coordinated list of 24 outcomes is presented within three outcome categories: Foundational, 
Technical and Professional. The outcomes define the desired level of achievement defined according to Bloom's Taxonomy for the cognitive domain ${ }^{3,4}$. Additionally, the BOK2 has recommended outcome achievement targets for each portion of the fulfillment pathway: for the baccalaureate degree (B), post-baccalaureate formal education (M/30), and pre-licensure experience (E). The emphasis herein is on those outcomes and achievement targets for the baccalaureate degree.

This paper is part of a suite of papers developed as part of a larger committee effort. ASCE's Body of Knowledge Educational Fulfillment Committee (BOKEdFC) was charged with examining how programs are responding to the $\mathrm{BOK} 2$ and possible ways the $\mathrm{BOK} 2$ outcomes may be integrated into civil engineering curricula. Previously, the BOKEdFC examined survey data illustrating how well programs, in their current design, achieve the educational outcomes of both the first and second editions of the civil engineering BOK. The purpose of this paper is to provide a comprehensive analysis of the University of Alabama's civil engineering curriculum with respect the BOK2 outcomes associated with the baccalaureate degree. Specific emphasis is given herein to these identified "challenging" outcomes. Curricular changes are then presented that would bring the curriculum into compliance with the BOK2, in addition to meeting current university graduation and $\mathrm{ABET} / \mathrm{EAC}$ accreditation requirements.

\section{Background}

As mentioned, the first edition of the Civil Engineering Body of Knowledge for the $2 I^{\text {st }}$ Century ${ }^{1}$ (BOK1) was released in January 2004, with a second edition (BOK2) released in February 2008. The emphasis of this paper is on the BOK2 and the BOK2 outcomes and achievement targeted for the baccalaureate degree.

The BOK2 Outcomes Rubric, using Bloom's Taxonomy, is graphically presented in Figure 1. The reader is cautioned that this is simple graphical representation of the full rubric only and should refer to the full rubric as presented in Appendix I of the BOK2 report ${ }^{2}$ (which is available at www.asce.org/raisethebar). What is clearly represented in Figure 1 is the recommended level of achievement that an individual must demonstrate for each outcome to enter the future practice of civil engineering at the professional level and, for each outcome, the level of achievement (LOA) expected to be fulfilled through the baccalaureate degree (B), the master's degree or equivalent post-baccalaureate formal education (M/30), and pre-licensure experience (E).

Recently, ASCE's Body of Knowledge (BOK) Educational Fulfillment Committee (BOKEdFC) conducted an analysis of how well civil engineering curricula, in their current design, achieve the educational outcomes of both the first and second editions of the civil engineering $\mathrm{BOK}^{5}$. The results of a curricular review by ten representative civil engineering programs were presented along with possible explanations as to why current curricula may fulfill or fall short of fulfilling specific outcomes. Figure 2 presents the results of one of the surveys, specifically one in which programs reported, for the BOK2 outcome rubric, at what level of achievement they believe all of the outcome statement is fulfilled by all of their baccalaureate graduates. A color coding was provided to assist with visualizing the results of the survey. Green cells indicate baccalaureate graduates of 8 to 10 programs are believed to be fulfilling the LOA, yellow cells indicate graduate of 5-7 programs are fulfilling the LOA, and red cells indicate baccalaureate graduates 
of 4 or less programs are fulfilling the specified LOA. To further help with visualizing the results, the first column of each table corresponding to the outcome number has been similarly color coded consistent with the LOA corresponding to the "B" level for each outcome. For example, Outcome 6 (Humanities) is colored red and shows that six of the ten (yellow) surveyed programs believe all of the outcome is fulfilled by all of their baccalaureate graduates at a LOA 1, five of ten (yellow) at a LOA 2, and three of ten (red) at the targeted LOA 3.

Based on the survey data and analysis, the BOKEdFC 5 concluded that several BOK2 outcomes may be "challenging" for many programs to address in today's civil engineering curricula. These include the nine "red outcomes" shown in Figure 2 (i.e., Outcomes 3 - Humanities, 4 Social Sciences, 10 - Sustainability, 11 - Contemporary Issues \& History, 12 - Risk \& Uncertainty, 17 - Public Policy, 18 - Business \& Public Administration, 19 - Globalization, and 20 - Leadership). In addition, the committee identified Outcomes 5 - Material Science and Outcome 24 - Professional \& Ethics as outcomes that may be challenging for programs to fully implement since these topics are typically included to some degree in most programs curricula, particularly professional and ethical behavior, yet there appeared to be a significant gap between where programs are and where the BOK2 envisions them to be (see Figure 2).

\section{Institutional Profile}

The University of Alabama is a major, comprehensive, student-centered research university founded in 1831 and began offering engineering courses in 1837. Today, the university enrolls nearly 30,000 students and contributes over $\$ 1.8$ billion to the state's economy ${ }^{6}$. The College of Engineering, with over 100 tenure/tenure-track faculty in eight departments, enrolls over 2200 undergraduate, 200 masters, and 120 doctoral students. In fiscal year 2008-09, externally-funded research expenditures in the college exceeded \$10 million. The Department of Civil, Construction, and Environmental Engineering has 20 tenure/tenure-track faculty, enrolls nearly 600 undergraduate, 32 masters, and 24 doctoral students. The department participates in many interdisciplinary research centers and is lead in three - the Aging Infrastructure Systems Center, the Environmental Institute, and the University Transportation Center for Alabama. Externallyfunded research expenditures in the department exceeded \$2.4 million during FY 2008-09.

\section{Current BSCE Curriculum}

The department offers the BSCE, which has been continuously accredited by ABET since 1936. The faculty supported and initiated a major curricular redesign which was completed and implemented in 2004 and addressed various local and national issues, including the BOK1 report. In 2008, following the release of the BOK2 report, a review of the BSCE curriculum and student learning outcomes was conducted. Some adjustments to specific course content were made and a revised set of program outcomes were developed and implemented Fall 2009.

The program outcomes used until Fall 2009 are provided in Table 1. ${ }^{*}$ The 12 outcomes were presented in two categories - technical (T1 - T7) and professional practice (P1 - P5). Bloom's taxonomy was used to establish the level of achievement. Table 2 provides the program

\footnotetext{
* Prior to the outcomes as presented in Table 1, the program outcomes were, in effect, simple restatements of the ABET criteria 3a-k plus the civil engineering program criteria.
} 
outcomes that were developed and implemented Fall 2009. The new outcomes are divided into three categories - foundational (F1 - F2), technical (T1 - T7), and professional practice (P1 P5). If one examines the two sets of outcomes (Tables 1 and 2), all components of the original outcomes (Table 1) are incorporated in the new outcomes (Table 2), with some reorganization and renumbering. Other changes were the result of consideration of the BOK2 outcomes.

The current (Fall 2009) curriculum is presented in Table 3, which follows the accustomed ABET/EAC self-study standard format. A couple notes of explanation follow:

Core Curriculum: The university has a core curriculum requirement which includes 6 semester credit hours of freshman composition (FC), 6 credit hours of "writing within the curriculum" in 300- and 400-level courses (W), 9 credit hours of humanities, literature, and fine arts (HU/L/FA), 9 credit hours of history and social and behavioral sciences (HI/SB), a 6 credit-hour depth (or sequence) study in a discipline in either HU/L/FA or HI/SB, 12 credit hours of natural science (NS) and mathematics (MA) to include 2 credit hours of laboratory (mathematics must be at the calculus I level or higher), and either 6 credit hours of foreign language (FL) or computer $(\mathrm{C})$ in addition to the HU/L/FA requirement (FL courses can count as $\mathrm{HU}$ credit if 6 credit hours of $\mathrm{C}$ are earned).

Senior Electives: A total of 18 semester credit hours of "senior electives" are allowed in the curriculum. Of the 18 credit hours, a minimum of 6 credit hours must be civil engineering "design-designated" (D) electives and a maximum of 6 credit hours may be "professional practice" (P) electives. The department maintains a listing of approved design-designated courses (which include a significant design experience) and professional-practice courses. While a few CE courses are listed as professional-practice, most $\mathrm{P}$ courses are from outside the department (e.g., business, other engineering disciplines, etc.).

Minors: With the 18 credit hours of senior electives, many students opt to pursue one or more minors to complement their BSCE degree. The department maintains six minors architectural engineering, civil engineering (for non-majors), construction engineering, environmental and water resources engineering, structural engineering, and transportation engineering. In addition, minors in business administration, mathematics, foreign language and other areas are commonly pursued. When pursuing a minor outside the department, the allowed two professional-practice electives are often used towards the minor.

\section{Evaluation of Current Curriculum vs. BOK2 Outcomes}

As mentioned, the BSCE program outcomes have evolved over time, largely in response to the ASCE BOK1 and BOK2 reports. Accordingly, curricular and course-content changes have been made to support the new and revised program outcomes. A comparison of the BOK2 baccalaureate outcomes and the current BSCE program outcomes (Table 2) is provided in Table 4. Some combination, integration, and/or rewording of the BOK2 outcomes was done to better reflect the emphasis and focus of the program and improve student understanding of the learning outcomes. As a result, some BOK2 outcomes may not be identically reflected in the program outcomes. Specific comments are included where differences or changes exist.

While not included in this paper, the faculty purposefully linked all outcomes to at least two courses (more for most outcomes) within the curriculum. Within each civil engineering course, 
students are required to submit a "course outcome portfolio" wherein the student documents their achievement of the course outcomes. At graduation and as part of the senior design course, students are required to submit a "graduation portfolio" in which the student documents their achievement of all program outcomes. Course-level portfolios are evaluated by the instructor as a part of the course grade. Graduation portfolios are evaluated by department faculty and members of the department's external advisory board.

Most of the curricular and course-content changes to support the change from the original program outcomes (Table 1) to the new program outcomes (Table 2) were made as a result of potential lack of educational development relative to one or more of the new outcomes. The result of the curricular and course-content changes was a curriculum (Table 3) that provides learning and assessment opportunities in support of the program outcomes (Table 2). Figure 3 is a graphical comparison of the BSCE program outcomes with the BOK2 rubric. For reference, the 11 "challenging" outcomes identified by the Body of Knowledge Educational Fulfillment Committee $^{5}$ are shaded red in the first column of the figure. Also represented in Figure 3, once again, is the recommended level of achievement expected to be fulfilled through the baccalaureate degree (B), the master's degree or equivalent post-baccalaureate formal education $(\mathrm{M} / 30)$, and pre-licensure experience $(\mathrm{E})$. The green shaded cells indicate the BOK2 outcomes that are fully fulfilled by the current BSCE curriculum; the yellow shaded cells indicate partial fulfillment of the outcome by the current curriculum. Note that for three BOK2 outcomes $(5,15$, and 22), graduates of the program exceed the LOA expectation, all or in part, defined by the BOK2. For four of the BOK2 outcomes $(3,4,12$, and 19), some aspect of the BOK2 outcomes is currently not expected to be met by the graduates of the program.

\section{Current Curriculum and the "Challenging" BOK2 Outcomes}

Considering the so-called "challenging" BOK2 outcomes as identified by the BOKEdFC", the current curriculum at the University of Alabama is considered to fully address some (outcomes 5, $10,11,17,20$, and 24) and not fully address others (outcomes 3, 4, 12, and 19). A more detailed discussion of how the curriculum addresses these "challenging" outcomes follows:

Outcome 3 - Humanities: The BOK2 envisions graduates with a bachelor's degree in civil engineering to "demonstrate the importance of the humanities in the professional practice of engineering." The university's core curriculum requires 9 credit hours of humanities, literature, and fine arts (HU/L/FA) but without any tie to the student's major. This outcome was restated using the University of Alabama's core curriculum terminology (i.e., HU/L/FA). At the University of Alabama, COM 123 Public Speaking is required in the civil engineering curriculum and holds HU core designation. The importance of the humanities to the practice of civil engineering is discussed in several courses, including the concept of form and function - that is consideration of civil works as both art and engineering - within the context of design. The program outcome, however, requires students to "explain" versus "demonstrate." How one "demonstrates the importance" was a concern of the faculty, but "explaining the importance" seemed more assessable. While many students may be able to "demonstrate" the importance through, for example, integration with certain design projects, most may not be exposed to such a broad experience.

Outcome 4 - Social Sciences: Similar to Outcome 3, the BOK2 aspires to have graduates "demonstrate the incorporation of social sciences knowledge into the professional practice of 
engineering." As part of the core curriculum, 9 credit hours of history and social and behavioral sciences (HI/SB) is requires, with three credit hours of EC 110 Microeconomics (SB) being required by the civil engineering curricula. The program outcome deviates from the BOK2 outcome in two ways: (1) the program outcome requires students to "explain..." versus "demonstrate..." and (2) the program changed "...the incorporation of..." to "...the importance of..." These changes were done to allow the humanities and social science outcomes to be combined and to aid in uniform assessment criteria. The importance of social science to the practice of civil engineering is discussed in several courses, particularly when public works and policy are a focus as in CE 350 Highway Design \& Construction and CE 320 Introduction to Environmental Engineering. Additionally, the department offers an SBdesignated elective, CE 220 Infrastructure, the Environment, and Society.

Outcome 5 - Material Science: The BOK2 envisions graduates to "use knowledge of materials science to solve problems appropriate to civil engineering." At the University of Alabama, this outcome is combined with BOK2 Outcome 6 - Mechanics and students are expected to "analyze" and "solve" rather than "use" and solve." The outcome is satisfied largely through the required course CE 262 Civil Engineering Materials. This course complements the traditional mechanics of materials lab and focused on both materials science and mechanics of several traditional and new materials used in civil engineering. Some other programs within the college actually allow their students the option of either CE 262 or MTE Engineering Materials: Structure and Properties, a more traditional materials science course. Subsequent courses in the civil engineering curriculum draw upon CE 262 content and require students to analyze more specific materials issues (e.g., pavement design, forensic engineering).

Outcome 10 - Sustainability: The BOK2 expects future graduates to "apply the principles of sustainability to the design of traditional and emergent engineering systems." Since the BOK2 outcomes explicitly ties sustainability to design, sustainability was formally integrated with the program's design outcome by stating the design must be conducted "including sustainability and within realistic constraints..." The premise is that sustainability is specific design criteria that must be considered. Sustainability concepts are covered as an integrative component within many introductory and design courses. Critical to this approach, sustainability is a required design criterion in the program's capstone design course, CE 401 Civil Engineering Design Project. Design professionals who specialize in sustainability (e.g., design engineers who are LEED AP) work closely with the students to include sustainability within their design and meet set sustainability criteria (e.g., LEED Silver, target innovation points, etc.). Additionally, students who elect to take one or more electives which emphasize sustainability actually gain a deeper understanding of sustainability principles.

Outcome 11 - Contemporary Issues \& History: The BOK2 expects students, "drawing upon a broad education, explain the impact of historical and contemporary issues on the identification, formulation, and solution of engineering problems and explain the impact of engineering solutions on the economy, environment, political landscape, and society." For the program outcome, "explain the impact ... on the identification, formulation, and solution of engineering problems" was changed to simply "explain the impact ... on civil engineering", "explain the impact of engineering solutions" was changed to "predict the impact of a specific, relatively constrained engineering solution", and "political landscape" 
was not included. The first part of the program outcome is intended to address principles and impacts from the past and present. The second part of the program outcome addresses the student's ability to apply these principles and ideas within the context of some limited-scope projects. The first part of the program outcome is achieved within the context of several courses and, specifically, in a nearly identical manner as what the humanities and social sciences outcomes are addressed. Additionally, a portion of CE 101 Introduction to Civil Engineering is dedicated to the impact historical and contemporary issues have on the profession. The second part of the outcome is likewise addressed in several courses, but is specifically addressed within courses wherein public works and policy are a focus, as in CE 350 Highway Design \& Construction and CE 320 Introduction to Environmental Engineering. Additionally, as noted previously, the department offers an SB-designated elective, CE 220 Infrastructure, the Environment, and Society, which requires students to predict potential impacts.

Outcome 12 - Risk \& Uncertainty: The BOK2 envisions graduates with a bachelor's degree in civil engineering to "apply the principles of probability and statistics to solve problems containing uncertainties." The program outcomes do not explicitly address the solution of problems containing uncertainties, but certainly address the application of principles of probability and statistics. The BSCE curriculum requires GES 255 Engineering Statistics I, an applied engineering probability and statistics course that does include, to some degree, solving problems with uncertainty. However, only students who take certain electives and, more specifically those qualified students who may take graduate courses such as CE 573 Statistical Applications in Civil Engineer, actually would fully satisfy this outcome.

Outcome 17 - Public Policy: Under the BOK2, future graduates will be expected to "discuss and explain key concepts and processes involved in public policy." The program outcome combines this outcome with BOK2 Outcome 18 - Business \& Public Administration and Outcome 19 - Globalization and expects graduates to "explain the importance of licensure, and basic concepts in engineering management, business, law, public administration, public policy, and globalization as related to the professional practice of civil engineering." The subtle difference is that the BOK2 expects students to "discuss and explain key concepts and processes" where the program expects students to "explain ... basic concepts in ... public policy." Public policy is introduced in CE 101 Introduction to Civil Engineering and further developed in two junior year required courses, CE 350 Highway Design \& Construction and CE 366 Project Management \& Economics. And like most program outcomes, this program outcome is also addressed integrally with the senior design course, CE 401 Civil Engineering Design Project.

Outcome 18 - Business \& Public Administration: Following the BOK2, graduates with a CE degree will be expected to "explain key concepts and processes used in business and public administration." As mentioned above, this BOK2 outcome is combined with BOK2 outcomes 17 and 19 to form a single program outcome. The difference is that the BOK2 expects students to "explain key concepts and processes" where the program expects students to "explain ... basic concepts." Like public policy, business and public administration is introduced in CE 101 Introduction to Civil Engineering and further developed in two junior year required courses, CE 350 Highway Design \& Construction and CE 366 Project Management \& Economics, and integral to CE 401 Civil Engineering Design Project. 
Outcome 19 - Globalization: This new outcome to the BOK2 expects students to "organize, formulate, and solve engineering problems within a global context." The combined program outcome that includes globalization requires graduates to "explain ... basic concepts in ... globalization as related to the professional practice of civil engineering." The level of achievement expected by the program is at level 2 while the BOK2 seeks level 3 . The same sequence of courses as described above for BOK2 Outcomes 17 and 18 are used to address globalization.

Outcome 20 - Leadership: The BOK2 envisions civil engineering graduates of the future to "apply leadership principles to direct the efforts of a small, homogenous group." The program outcome combines the BOK2 leadership outcome with the BOK2 outcomes related to attitudes and teamwork, and expects students to "demonstrate attributes supportive of the professional practice of engineering; apply leadership principles to direct the efforts of a small group to solve a relatively constrained problem; and function effectively as a member of a multidisciplinary team to solve open-ended engineering problems." Relative to leadership, the wording of the BOK2 and program outcomes are identical. Leadership principles are introduced, along with principles related to teamwork and attitudes in CE 101 and GES 131 Foundations of Engineering I. Additionally, all civil engineering lab courses in the sophomore and junior years specifically address this program outcome, and like so many other programs, CE 401 Civil Engineering Design Project is a team-based project which expects each student to take on a leadership role at various times during the term.

Outcome 24 - Professional \& Ethics: The BOK2 outcome expecting graduates to "analyze a situation involving multiple conflicting professional and ethical interests to determine an appropriate course of action" is not new to civil engineering curricula. The associated program outcome expects graduates to "analyze a situation involving multiple conflicting professional, legal, and ethical interests to determine an appropriate course of action." The program adds "legal interests" in addition to professional and ethical. The three topics are introduced in CE 101, and then developed fully in CE 350 Highway Design \& Construction and CE 320 Introduction to Environmental Engineering. Again, like most program outcomes, this program outcome is also addressed integrally with the senior design course, CE 401 Civil Engineering Design Project.

\section{Curricular Changes Needed to Fully Implement the BOK2}

The curriculum as presented (Table 3) was originally designed and, through assessment, verified to have met the original program outcomes (Table 1). The new program outcomes (Table 2) were implemented for the Fall 2009 term with no significant curricular changes (i.e., some modest course-level adjustments were made to address some of changes). That is, the faculty considered the curriculum, as it stood, to support student achievement of the new program outcomes. To evaluate this assumption, the student achievement of the new outcomes was assessed for all December 2009 graduates. This was done through the use of student graduation portfolios. Additionally, qualitative assessment data and insights were drawn from senior exit interviews. All graduating seniors are required to meet, as a group, with the department head to discuss their experience at the university, within the program, and the curriculum specifically.

As a requirement for graduation, students submit a graduation outcome portfolio. This is done in conjunction with the senior design project course. Students must show in their portfolio 
appropriate achievement of all program outcomes. They are required to have a separate section of the portfolio to address each program outcome. Students are required to provide documentation, in the form of assignments or other work associated with their academic program (which may include approved extra- and co-curricular activities, cooperative education experience, internships, etc.) that they feel accurately demonstrates their achievement of the each program outcome. The graduation portfolios are reviewed by faculty, members of the department's advisory board, and other representatives from the programs defined constituency groups.

The evaluation of individual student graduation portfolios is done with a simple evaluation form that requests evaluation for each program outcome based on information provided by the student. A five-point Likert scale is used for the evaluation, wherein 1 implies significant improvement is needed, 2 means slight improvement is needed, 3 signifies that students satisfactory meet the expectation, 4 means the students moderately exceed expectation, and 5 means outstanding performance. Additionally, all evaluators, which include both external constituencies and faculty, are asked to provide observations or information to support their assessment rating. When an average rating less than 3.0 "students satisfactorily meet expectations" occurs for any outcome, it becomes a priority consideration for the faculty.

Table 5 provides summary data for the Fall 2009 graduation portfolio, respectively. The average, standard deviation, and coefficient of variation data for the entire graduating class is provided for the each outcome. Additionally, the outcome rating for each student (identified anonymously) is provided. As noted in Table 5, all outcomes exceeded the threshold with an average assessment value greater than 3.0 "satisfactory, meets expectation". In fact, no outcome had an average assessment less than 3.2 for outcomes F2 and P5. The next lowest performance was a 3.3 for outcome P1.

Outcome F2 is a completely new outcome related to humanities and social science which states students must "Explain the importance of (1) humanities, literature, and fine arts, and (2) history and social behavior in the professional practice of civil engineering." While the program requires a total of 18 credit hours in these areas, the students were found to have a difficulty in documenting their ability to "explain the importance" of these subjects "in the professional practice of civil engineering." During a group exit interview with all the graduating seniors, they identified this outcome as the most difficult, in their opinion, to document. They strongly supported the inclusion of a program outcome relative to the humanities and social sciences, but felt the curriculum did not help them explain the importance to professional practice per se. The students recommended the faculty consider changing the working of the outcome and delete reference to "the professional practice of civil engineering." They felt that having a basic understanding of the overall importance of the arts, humanities, social sciences, and history was sufficient. They students further suggested that they would not favor any restriction placed on what courses in the humanities and social sciences would be allowed so as to better satisfy the current outcome wording.

The wording of Outcome P5 changed based on the BOK2 from "Explain the importance of licensure, and basic concepts in engineering management, business, public policy, and leadership" to "Explain the importance of licensure, and the basics of business, law, public 
administration, public policy, and globalization as related to the professional practice of civil engineering." The previous academic year assessment for this outcome was a 3.6. In reviewing the assessment data and portfolio evaluator comments, the drop in performance was directly related to the addition of law and globalization. During the senior exit interview, students commented that many recalled course content related to these subjects, but they could not find material to document their understanding of law and globalization. Faculty also noted that since these subjects were not included in the formal outcome until the Fall 2009 term, they may not have included sufficient course work to support student learning and eventual documentation of achievement. This is one area that faculty felt required modest course-level modifications to assure the subject matter was covered in key courses.

Outcome P1 is unchanged for the new BOK2-conforming program outcomes and states that students must "Analyze a situation involving multiple conflicting professional, legal, and ethical interests to determine an appropriate course of action." Last academic year, the assessment for this outcome was a 3.6. In reviewing the assessment data and portfolio evaluator comments, the drop in performance appeared related to dealing with "multiple conflicting...interests." The evaluators did not see evidence of multiple issues being dealt within a single problem. While this is not an issue directly related to BOK2, as this outcome has been in place for the program prior to the introduction of the BOK2-conforming outcomes, it may be that students simply did not document this outcome as well in lieu of trying to document some of the new outcome expectations. This outcome, though, was not discussed during senior exit interviews.

\section{The BOK2-Conforming Curriculum}

The curriculum (Table 3) which was in place prior to the adoption of the new BOK2-conforming program outcomes (Table 2) appears to generally satisfy the outcome expectations of the BOK2. This is supported by the assessment data for the December 2009 graduates. These students completed the curriculum that was designed to support ABET and BOK1 outcomes (Table 1) but were assessed against the new BOK2-conforming outcomes (Table 2). Two primary issues must be addressed to be fully confident in program compliance with the BOK2. First, some course-level adjustments would be required to assure that the new topics that have been integrated into existing outcomes are directly and explicitly addressed. For example, globalization and law as discussed relative to program outcome P5.

The second issue is related to the BOK2 outcomes on humanities and social sciences. The program outcome states that students must "explain the importance of (1) humanities, literature, and fine arts, and (2) history and social behavior in the professional practice of civil engineering." The faculty is considering two alternatives. The first is to simply delete reference to "in the professional practice of civil engineering." While this may not fully comply with the BOK2, it does assume that civil engineering graduates who can explain the importance of the humanities and social science in general can ultimately benefit the profession. The second alternative is to limit the selection of humanities and social science courses by civil engineering students, then explicitly relate the content of theses limited courses to the professional practice of civil engineering within specific civil engineering courses. This alternative is not supported by students and initially does not have faculty support either. 


\section{Conclusions}

This paper provides a complete analysis of the undergraduate civil engineering curriculum at the University of Alabama relative to the second edition of the Civil Engineering Body of Knowledge for the $21^{\text {st }}$ Century (BOK2). Specific emphasis is given those BOK2 outcomes that the aforementioned survey data identified as being a challenge for many programs to address within current curricular design. The curriculum, as developed, is considered to be BOK2-conforming, in addition to meeting current university graduation and ABET/EAC accreditation requirements.

The curriculum as presented was originally designed and, through assessment, verified to have met program outcomes that satisfied ABET and the first edition of the Civil Engineering Body of Knowledge for the $21^{\text {st }}$ Century (BOK1). New program outcomes were developed and implemented for the Fall 2009 term with no significant curricular changes (i.e., some modest course-level adjustments were made to address some of changes). To evaluate the performance of the existing curriculum against the BOK2-conforming outcomes, the achievement of the December 2009 class were assessed against the new outcomes. This assessment was done through the use of student graduation portfolios. Additionally, qualitative assessment data and insights were drawn from senior exit interviews.

The evaluation of individual student graduation portfolios was done with a simple evaluation form that requests evaluation for each program outcome based on information provided by the student. A five-point Likert scale is used for the evaluation, wherein 1 implies significant improvement is needed, 2 means slight improvement is needed, 3 signifies that students satisfactory meet the expectation, 4 means the students moderately exceed expectation, and 5 means outstanding performance. The program's policy requires an average rating of at least 3.0 "students satisfactorily meet expectations", or else it becomes a priority consideration for the faculty to make programmatic changes to improve student learning and achievement.

Based on the analysis of the assessment data of the Fall 2009 graduation portfolios, all program outcomes exceed the established criteria of a 3.0, thus it is concluded that graduates of the curriculum generally satisfy the BOK2 outcomes. The three lowest performing program outcomes are, in order, F2, P5, and P1. The faculty fully recognize the modest differences between the program outcomes and the BOK2 outcomes. These differences are due to some integration of BOK2 outcomes and wording changes that the faculty feel were appropriate to better communicate the outcome to students. However, the faculty also feel the differences were well within what is commonly accepted with current ABET outcome statements. That is, there is no mandate that exact ABET's exact wording or organization of the outcomes be retained by a program. Thus, since the BOK2 outcomes are new and "untested", the faculty feel what was adopted as program outcomes fully support the intent and vision of the BOK2.

Outcome F2 is a completely new outcome related to humanities and social science which states students must "Explain the importance of (1) humanities, literature, and fine arts, and (2) history and social behavior in the professional practice of civil engineering." Students had a difficulty in relating their coursework in the humanities and social science explicitly to the professional practice of civil engineering. The faculty is considering deleting reference to "in the professional practice of civil engineering." While this may not fully comply with the BOK2, it does assume 
that civil engineering graduates who can explain the importance of the humanities and social science in general can ultimately benefit the profession

The wording of Outcome P5 changed based on the BOK2 from "Explain the importance of licensure, and basic concepts in engineering management, business, public policy, and leadership" to "Explain the importance of licensure, and the basics of business, law, public administration, public policy, and globalization as related to the professional practice of civil engineering." The primary issue in this outcome is related to the addition of law and globalization. Faculty noted that since these subjects were not included in the formal outcome statements until the Fall 2009 term, they may not have included sufficient course work to support student learning and eventual documentation of achievement. The faculty will develop modest course-level modifications to assure the subject matter was covered in key courses.

Outcome P1 is unchanged for the new BOK2-conforming program outcomes and states that students must "Analyze a situation involving multiple conflicting professional, legal, and ethical interests to determine an appropriate course of action." The lower performance of this outcome appeared related to dealing with "multiple conflicting...interests." The evaluators did not see evidence of multiple issues being dealt within a single problem. While this is not an issue directly related to $\mathrm{BOK} 2$, as this outcome has been in place for the program prior to the introduction of the BOK2-conforming outcomes, it may be that students simply did not document this outcome as well in lieu of trying to document some of the new outcome expectations.

All things considered, the faculty considers new program outcomes and associated curricular redesign to be well worth the effort. The faculty consensus is that students have an increased understanding (1) of how the program supports their potential as a future professional, (2) in the expectations for graduation (versus just their courses), and (3) ownership in their own education.

\section{Bibliography}

1. ASCE Body of Knowledge Committee of CAP^3. 2004. Civil Engineering Body of Knowledge for the $21^{\text {st }}$ Century: Preparing the Civil Engineer for the Future, Reston, VA, January. (http://www.asce.org/raisethebar).

2. ASCE Body of Knowledge II Committee of $\mathrm{CAP}^{\wedge} 3.2008$. Civil Engineering Body of Knowledge for the $21^{\text {st }}$ Century: Preparing the Civil Engineer for the Future, Second Edition, Reston, VA, January. (http://www.asce.org/raisethebar).

3. ASCE Levels of Achievement Subcommittee of CAP^3. 2005. Levels of Achievement Applicable to the Body of Knowledge Required for Entry Into the Practice of Civil Engineering at the Professional Level, Reston, VA, September. (http://www.asce.org/raisethebar)

4. Bloom. B. S., Englehart, M. D., Furst. E. J., Hill, W. H., and Krathwohl, D. 1956. Taxonomy of Educational Objectives, the Classification of Educational Goals, Handbook I: Cognitive Domain. David McKay, New York, NY.

5. Fridley, K.J., et al., 2009. Educating the Future Civil Engineering for the New Civil Engineering Body of Knowledge," Proceeding of the 2009 ASEE Annual Conference, June 2009, Austin, TX.

6. University of Alabama. 2009. Annual Report: Performance Indicators. The University of Alabama, Tuscaloosa, AL. 


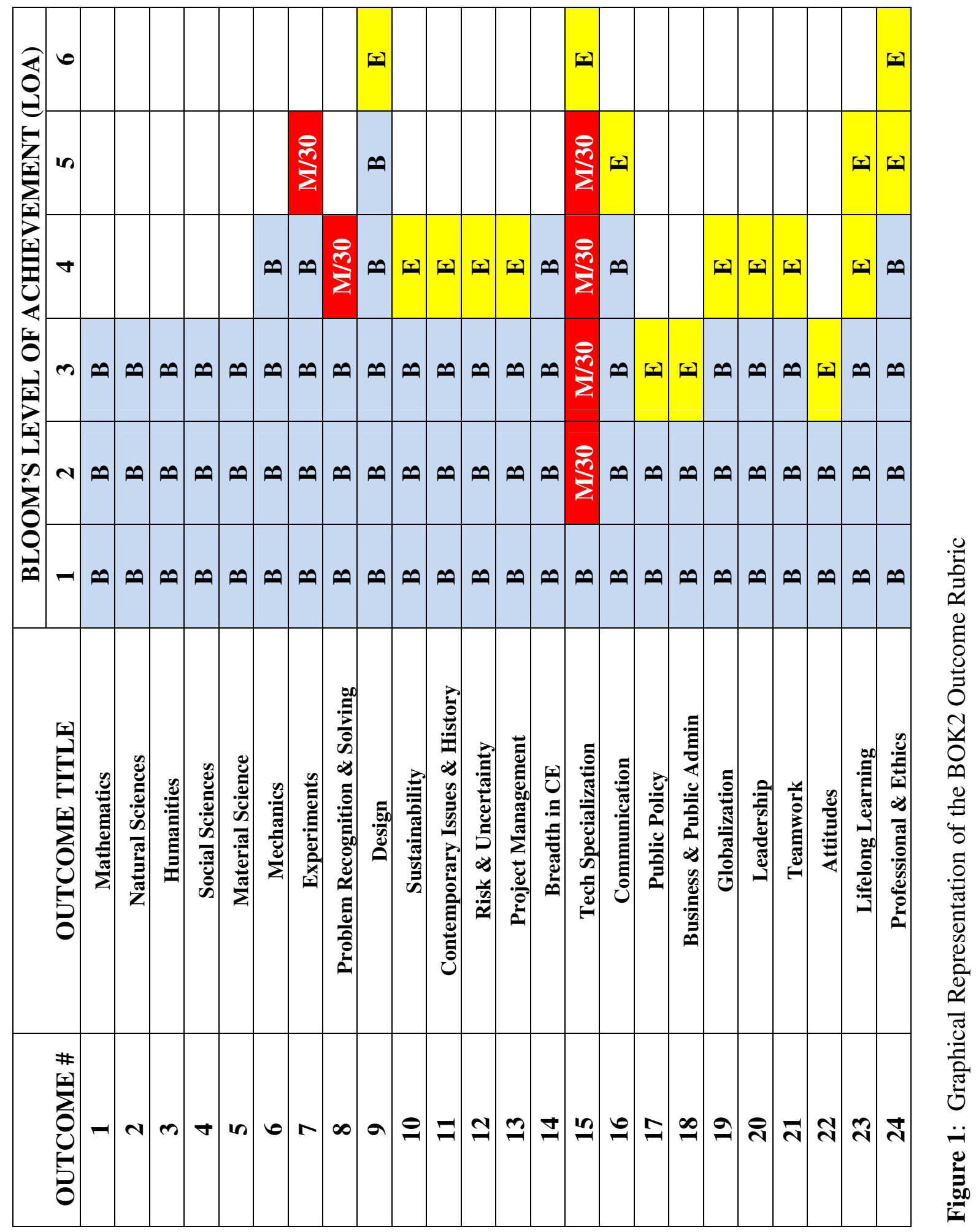

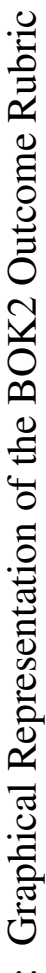

تِّ 


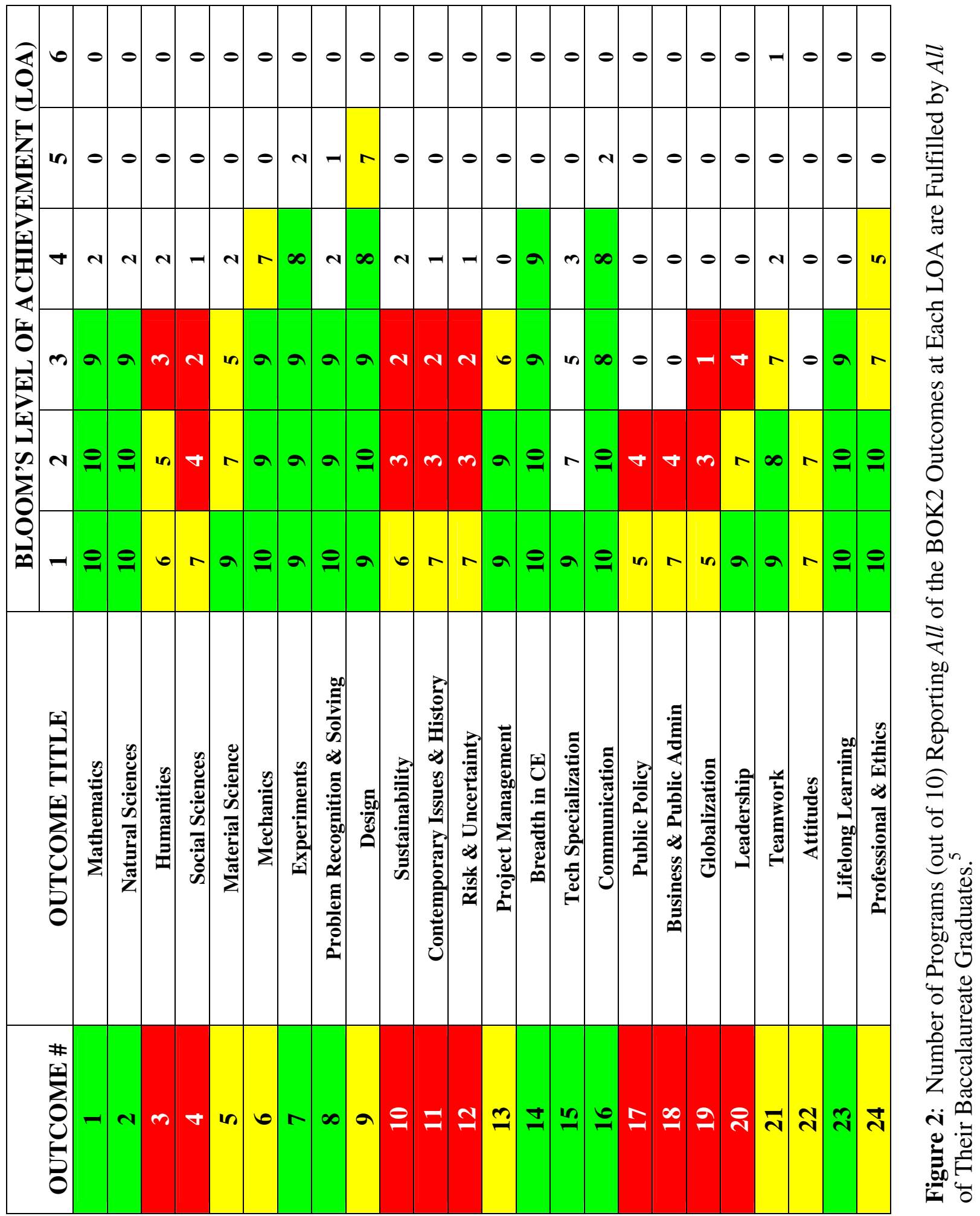


Table 1: The University of Alabama's BSCE Program Outcomes Prior to Fall 2009.

\begin{tabular}{|c|c|}
\hline $\begin{array}{l}\text { Outcome T1: } \\
\text { (Level 3) }\end{array}$ & $\begin{array}{l}\text { Solve problems in mathematics through differential equations, probability and statistics, } \\
\text { calculus-based physics, general chemistry, and one additional area of science. }\end{array}$ \\
\hline $\begin{array}{l}\text { Outcome T2: } \\
\text { (Level } 4)\end{array}$ & $\begin{array}{l}\text { Select and conduct program-relevant civil engineering experiments to meet a need, and } \\
\text { analyze and evaluate the resulting data. }\end{array}$ \\
\hline $\begin{array}{l}\text { Outcome T3 } \\
\text { for BSCE: } \\
\text { (Level 3) }\end{array}$ & $\begin{array}{l}\text { Apply relevant knowledge, techniques, skills, and modern engineering tools to identify, } \\
\text { formulate, and solve engineering problems, including problems in at least four technical } \\
\text { areas appropriate to civil engineering. }\end{array}$ \\
\hline $\begin{array}{l}\text { Outcome T4: } \\
\text { (Level 5) }\end{array}$ & $\begin{array}{l}\text { Design a system or process in more than one program-relevant civil engineering context } \\
\text { to meet desired needs, within realistic constraints such as economic, environmental, } \\
\text { social, political, ethical, health and safety, constructability, and sustainability. }\end{array}$ \\
\hline $\begin{array}{l}\text { Outcome T5: } \\
\text { (Level 3) }\end{array}$ & $\begin{array}{l}\text { Predict possible global, economic, environmental, and societal impacts of a specific, } \\
\text { relatively constrained engineering solution. }\end{array}$ \\
\hline $\begin{array}{l}\text { Outcome T6: } \\
\text { (Level 3) }\end{array}$ & Function effectively as a member of a multidisciplinary team. \\
\hline $\begin{array}{l}\text { Outcome T7: } \\
\text { (Level 2) }\end{array}$ & $\begin{array}{l}\text { Explain key aspects of at least one traditional or emerging area of advanced } \\
\text { specialization within the context of civil engineering. }\end{array}$ \\
\hline $\begin{array}{l}\text { Outcome P1: } \\
\text { (Level } 4)\end{array}$ & $\begin{array}{l}\text { Analyze a situation involving multiple conflicting professional, legal, and ethical interests } \\
\text { to determine an appropriate course of action. }\end{array}$ \\
\hline $\begin{array}{l}\text { Outcome P2: } \\
\text { (Level 4) }\end{array}$ & Organize and deliver effective written, verbal, graphical and virtual communications. \\
\hline $\begin{array}{l}\text { Outcome P3: } \\
\text { (Level 3) }\end{array}$ & $\begin{array}{l}\text { Demonstrate the ability to learn through independent study, without the aid of formal } \\
\text { instruction. }\end{array}$ \\
\hline $\begin{array}{l}\text { Outcome P4: } \\
\text { (Level 3) }\end{array}$ & $\begin{array}{l}\text { Demonstrate the ability to incorporate contemporary issues into the identification, } \\
\text { formulation, and solution of an engineering problem. }\end{array}$ \\
\hline $\begin{array}{l}\text { Outcome P5: } \\
\text { (Level 2) }\end{array}$ & $\begin{array}{l}\text { Explain the importance of licensure, and basic concepts in engineering management, } \\
\text { business, public policy, and leadership. }\end{array}$ \\
\hline
\end{tabular}


Table 2: The University of Alabama's BSCE Program Outcomes Effective Fall 2009.

\begin{tabular}{|c|c|}
\hline gineering & achelor of Science in Construction Engineering program will be able to: \\
\hline $\begin{array}{l}\text { Outcome F1: } \\
\text { (Level 3) }\end{array}$ & $\begin{array}{l}\text { Solve problems in mathematics through differential equations, probability and statistics, } \\
\text { calculus-based physics, general chemistry, and one additional area of science. }\end{array}$ \\
\hline $\begin{array}{l}\text { Outcome F2: } \\
\text { (Level 3) }\end{array}$ & $\begin{array}{l}\text { Explain the importance of (1) humanities, literature, and fine arts, and (2) history and } \\
\text { social behavior in the professional practice of civil engineering. }\end{array}$ \\
\hline $\begin{array}{l}\text { Outcome T1: } \\
\text { (Level 4) }\end{array}$ & $\begin{array}{l}\text { Analyze and solve problems in materials science, mechanics of solids, and mechanics of } \\
\text { fluids. }\end{array}$ \\
\hline $\begin{array}{l}\text { Outcome T2: } \\
\text { (Level 4) }\end{array}$ & $\begin{array}{l}\text { Select and conduct program-relevant civil engineering experiments to meet a need, and } \\
\text { analyze and evaluate the resulting data. }\end{array}$ \\
\hline $\begin{array}{l}\text { Outcome T3: } \\
\text { (Level 3) }\end{array}$ & $\begin{array}{l}\text { Apply relevant foundational and technical knowledge, techniques, skills, and modern } \\
\text { engineering tools to identify, formulate, and solve engineering problems, including } \\
\text { problems in at least four technical areas appropriate to civil engineering. }\end{array}$ \\
\hline $\begin{array}{l}\text { Outcome T4: } \\
\text { (Level 3) }\end{array}$ & $\begin{array}{l}\text { Explain the impact of historical and contemporary issues on civil engineering, and predict } \\
\text { possible impacts of a specific, relatively constrained engineering solution on the economy, } \\
\text { environment, and society. }\end{array}$ \\
\hline $\begin{array}{l}\text { Outcome T5: } \\
\text { (Level 3) }\end{array}$ & Develop solutions to well-defined project management problems within civil engineering. \\
\hline $\begin{array}{l}\text { Outcome T6: } \\
\text { (Level 5) }\end{array}$ & $\begin{array}{l}\text { Design a system or process in more than one program-relevant civil engineering context to } \\
\text { meet desired needs, including sustainability and within realistic constraints such as } \\
\text { economic, environmental, social, political, ethical, health and safety, and constructability. }\end{array}$ \\
\hline $\begin{array}{l}\text { Outcome T7: } \\
\text { (Level 2) }\end{array}$ & $\begin{array}{l}\text { Explain key aspects of at least one traditional or emerging program-relevant area of } \\
\text { advanced specialization. }\end{array}$ \\
\hline $\begin{array}{l}\text { Outcome P1: } \\
\text { (Level 4) }\end{array}$ & $\begin{array}{l}\text { Analyze a situation involving multiple conflicting professional, legal, and ethical interests } \\
\text { to determine an appropriate course of action. }\end{array}$ \\
\hline $\begin{array}{l}\text { Outcome P2: } \\
\text { (Level 4) }\end{array}$ & Organize and deliver effective written, verbal, graphical and virtual communications. \\
\hline $\begin{array}{l}\text { Outcome P3: } \\
\text { (Level 3) }\end{array}$ & $\begin{array}{l}\text { Demonstrate the ability to learn through independent study, without the aid of formal } \\
\text { instruction. }\end{array}$ \\
\hline $\begin{array}{l}\text { Outcome P4: } \\
\text { (Level 3) }\end{array}$ & $\begin{array}{l}\text { Demonstrate attributes supportive of the professional practice of engineering; apply } \\
\text { leadership principles to direct the efforts of a small group to solve a relatively constrained } \\
\text { problem; and function effectively as a member of a multidisciplinary team to solve open- } \\
\text { ended engineering problems. }\end{array}$ \\
\hline $\begin{array}{l}\text { Outcome P5: } \\
\text { (Level 2) }\end{array}$ & $\begin{array}{l}\text { Explain the importance of licensure, and the basics of business, law, public administration, } \\
\text { public policy, and globalization as related to the professional practice of civil engineering. }\end{array}$ \\
\hline
\end{tabular}


Table 3: The University of Alabama's Bachelor of Science in Civil Engineering Curriculum.

\begin{tabular}{|c|c|c|c|c|c|}
\hline & & & Category (Credi & Hours) & \\
\hline $\begin{array}{c}\text { Year, } \\
\text { Semester, or } \\
\text { Quarter }\end{array}$ & Course (Department, Number, Title) & $\begin{array}{c}\text { Math \& } \\
\text { Basic } \\
\text { Sciences } \\
\end{array}$ & $\begin{array}{l}\text { Engineering Topics } \\
\text { Check if Contains } \\
\text { Significant Design }(\checkmark)\end{array}$ & $\begin{array}{c}\text { General } \\
\text { Education }\end{array}$ & Other \\
\hline Year 1 & CH 101 General Chemistry I (NS) & 4 & & & \\
\hline 1st Semester & GES 131 Foundations of Engineering I & & & & 2 \\
\hline & EN 101 English Composition (FC) & & & 3 & \\
\hline & MATH 125 Calculus I (MA) & 4 & & & \\
\hline & EC 110 Principles of Microeconomics (SB) & & & 3 & \\
\hline & DR 100 Sketching & & & & 1 \\
\hline & & & & & \\
\hline Year 1 & CE 101 Introduction to Civil Engineering & & 1 & & \\
\hline 2nd Semester & EN 102 English Composition II (FC) & & & 3 & \\
\hline & MATH 126 Calculus II (MA) & 4 & & & \\
\hline & PH 105 Gen. Physics I w/Calculus (NS) & 4 & & & \\
\hline & DR 133 2D AutoCAD & & & & 2 \\
\hline & GES 132 Foundations of Engineering II & & & & 2 \\
\hline & & & & & \\
\hline Year 2 & AEM 201 Statics & & 3 & & \\
\hline 1st Semester & CE 260 Surveying & & 3 & & \\
\hline & MATH 227 Calculus III (MA) & 4 & & & \\
\hline & $\begin{array}{l}\text { CH } 102 \text { Gen. Chem II or } \\
\text { PH } 106 \text { Gen. Physics II/w Calculus (NS) }\end{array}$ & 4 & & & \\
\hline & HU/L/FA (core education) & & & 3 & \\
\hline & & & & & \\
\hline Year 2 & CE 262 CE Materials & & 3 & & \\
\hline 2nd Semester & AEM 250 Mechanics of Materials & & 3 & & \\
\hline & AEM 251 Mechanics of Materials Lab & & 1 & & \\
\hline & AEM 264 Dynamics & & 3 & & \\
\hline & MATH 238 Applied Differential Equations I (MA) & 3 & & & \\
\hline & Natural Science Elective (NS) & 4 & & & \\
\hline Year 3 & CE 331 Intro to Structural Engineering (C) & & 4 & & \\
\hline 1st Semester & CE 340 Geotechnical Engineering & & 4 & & \\
\hline & CE 366 Project Management \& Economics & & 3 & & \\
\hline & AEM 311 Fluid Mechanics & & 3 & & \\
\hline & HI/SB (core education) & & & 3 & \\
\hline & & & 4 & & \\
\hline$\frac{\text { Year 3 }}{\text { 2nd Semester }}$ & \begin{tabular}{|l|} 
CE 350 Highway Design \& Construction \\
CE 320 Intro to Environmental Engineering (W)
\end{tabular} & & $\frac{4}{3}$ & & \\
\hline & CE 378 Water Resources Engineering $(\mathrm{C})$ & & $4(\checkmark)$ & & \\
\hline & $\begin{array}{l}\text { ECE } 320 \text { Fundamentals of Electrical Engineering or } \\
\text { ME 216Thermal Engineering }\end{array}$ & & 3 & & \\
\hline & HI/SB (core education) & & & 3 & \\
\hline
\end{tabular}


Table 3. The University of Alabama's Bachelor of Science in Civil Engineering Curriculum Continued.

\begin{tabular}{|c|c|c|c|c|c|c|}
\hline \multirow[b]{2}{*}{$\begin{array}{c}\text { Year, } \\
\text { Semester, or } \\
\text { Quarter }\end{array}$} & \multirow{2}{*}{\multicolumn{2}{|c|}{ Course (Department, Number, Title) }} & \multicolumn{4}{|c|}{ Category (Credit Hours) } \\
\hline & & & $\begin{array}{l}\text { Math \& } \\
\text { Basic } \\
\text { Sciences }\end{array}$ & $\begin{array}{l}\text { Engineering Topics } \\
\text { Check if Contains } \\
\text { Significant Design }(\mathfrak{})\end{array}$ & $\begin{array}{c}\text { General } \\
\text { Education }\end{array}$ & Other \\
\hline Year 4 & \multicolumn{2}{|c|}{ Senior Elective } & & 3 or 0 & & 0 or 3 \\
\hline \multirow[t]{4}{*}{ 1st Semester } & \multicolumn{2}{|c|}{ Senior Elective } & & 3 or 0 & & 0 or 3 \\
\hline & \multicolumn{2}{|c|}{ Senior Elective } & & 3 & & \\
\hline & \multicolumn{2}{|c|}{ GES 255 Engineering Statistics I } & 3 & & & \\
\hline & \multicolumn{2}{|c|}{ COM 123 Public Speaking (HU) } & & & 3 & \\
\hline Year 4 & \multicolumn{2}{|c|}{ CE 401 Civil Engineering Design Project (W, C) } & & $4(\checkmark)$ & & \\
\hline \multirow{4}{*}{ 2nd Semester } & \multicolumn{2}{|c|}{ Senior Elective } & & 3 & & \\
\hline & \multicolumn{2}{|c|}{ Senior Elective (Design) } & & $3(\checkmark)$ & & \\
\hline & \multicolumn{2}{|c|}{ Senior Elective (Design) } & & $3(\checkmark)$ & & \\
\hline & \multicolumn{2}{|c|}{ HU/L/FA (core education) } & & & 3 & \\
\hline \multicolumn{3}{|c|}{ TOTALS-ABET BASIC-LEVEL REQUIREMENTS } & 34 & $\begin{array}{l}67 \text { max* } \\
61 \min ^{*}\end{array}$ & 24 & $\begin{array}{l}7 \text { min } \\
13 \max \end{array}$ \\
\hline \multicolumn{3}{|c|}{ Overall Total Credit Hours for Degree } & 132 & & & \\
\hline \multicolumn{3}{|c|}{ PERCENT OF TOTAL } & $25.8 \%$ & $\begin{array}{l}50.8 \% \max ^{*} \\
46.2 \% \text { min* }\end{array}$ & $18.2 \%$ & $\begin{array}{c}5.3 \% \\
\min \\
4.6 \% \\
\min \\
\end{array}$ \\
\hline \multirow{2}{*}{\multicolumn{2}{|c|}{$\begin{array}{c}\text { Totals must } \\
\text { satisfy one set }\end{array}$}} & Minimum semester credit hours & $32 \mathrm{hrs}$ & $48 \mathrm{hrs}$ & & \\
\hline & & Minimum percentage & $25 \%$ & $37.5 \%$ & & \\
\hline
\end{tabular}




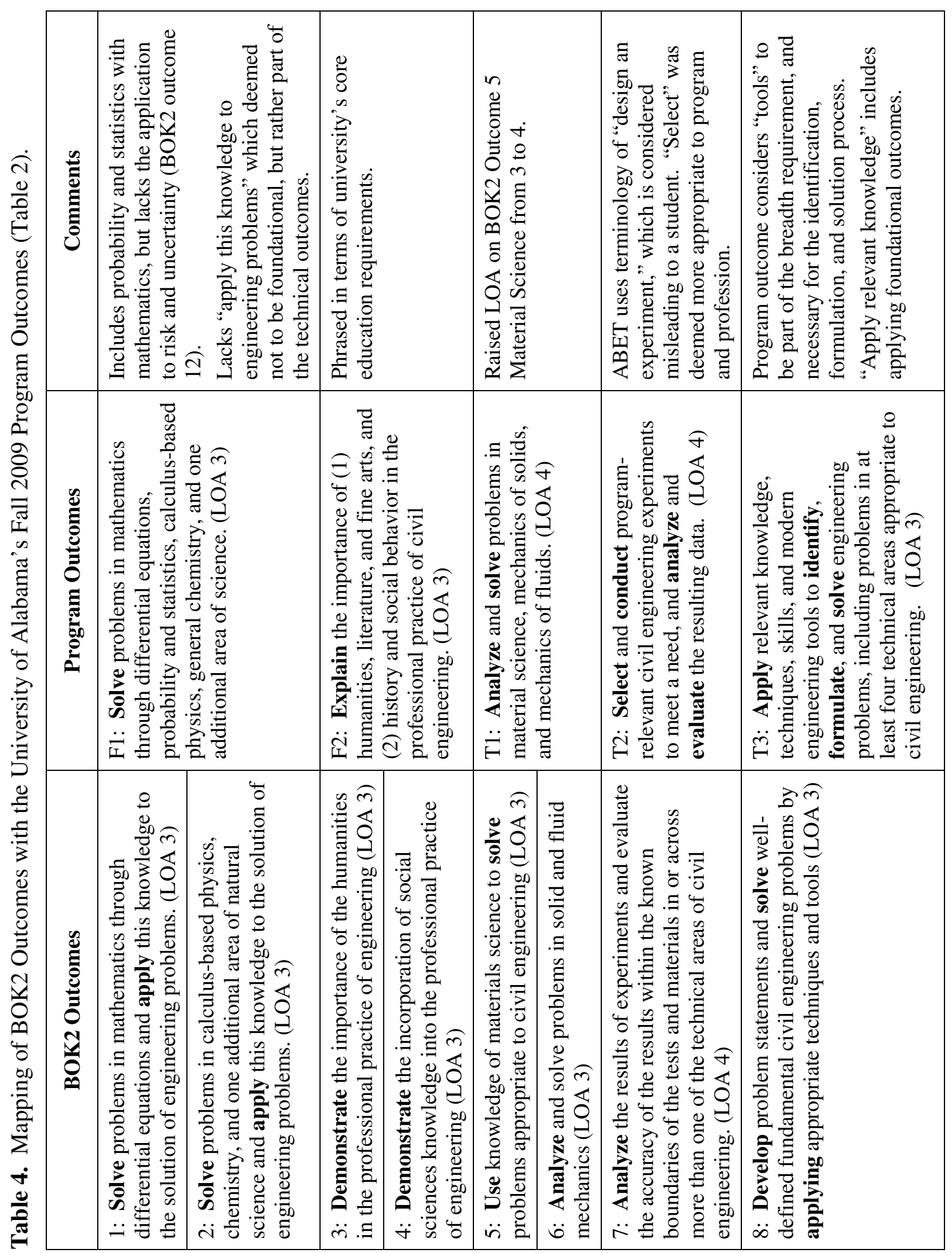

0
$\mathscr{0}$
0
0
$\overrightarrow{0}$
ò
$\ldots$
ते 


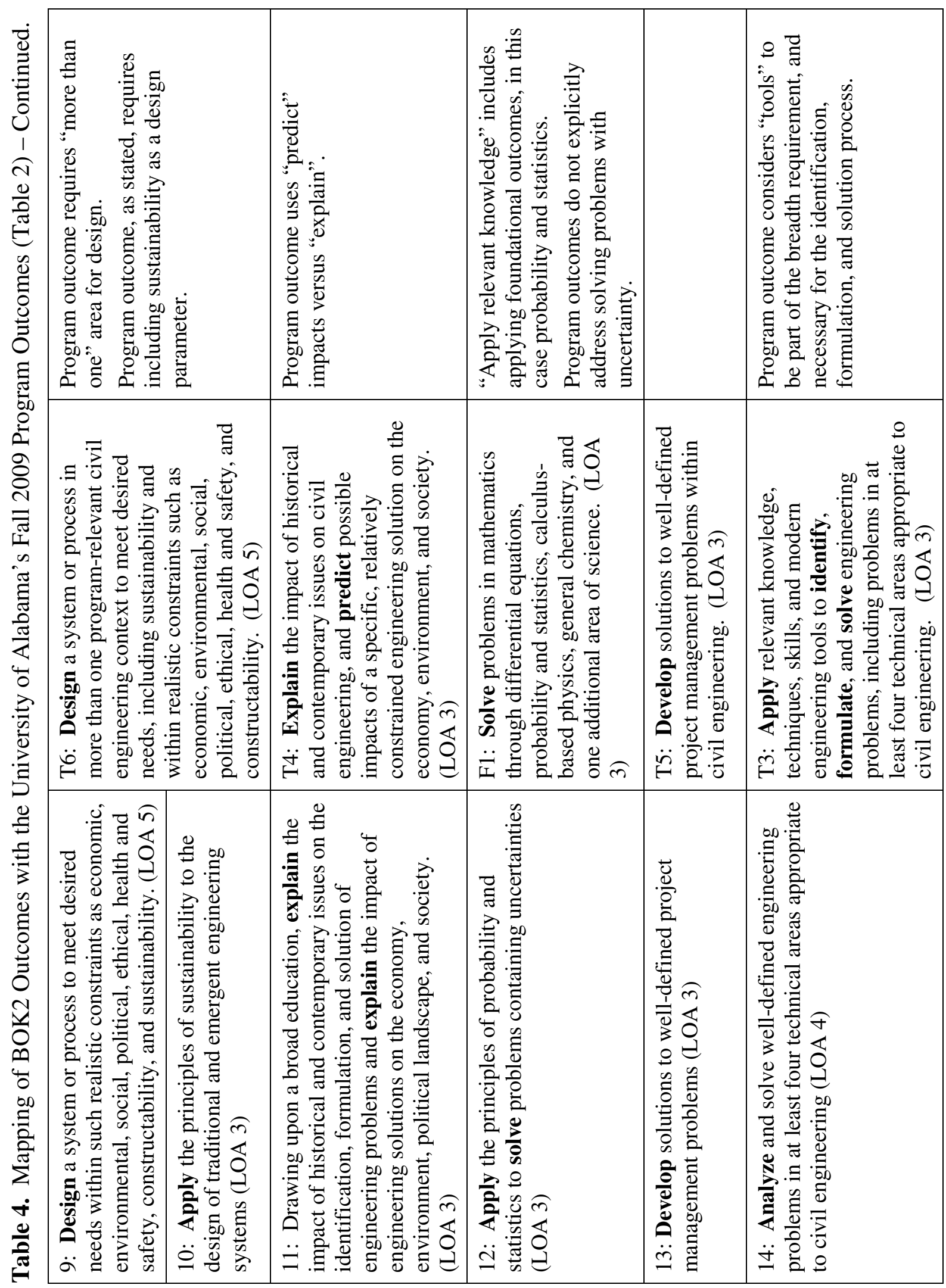




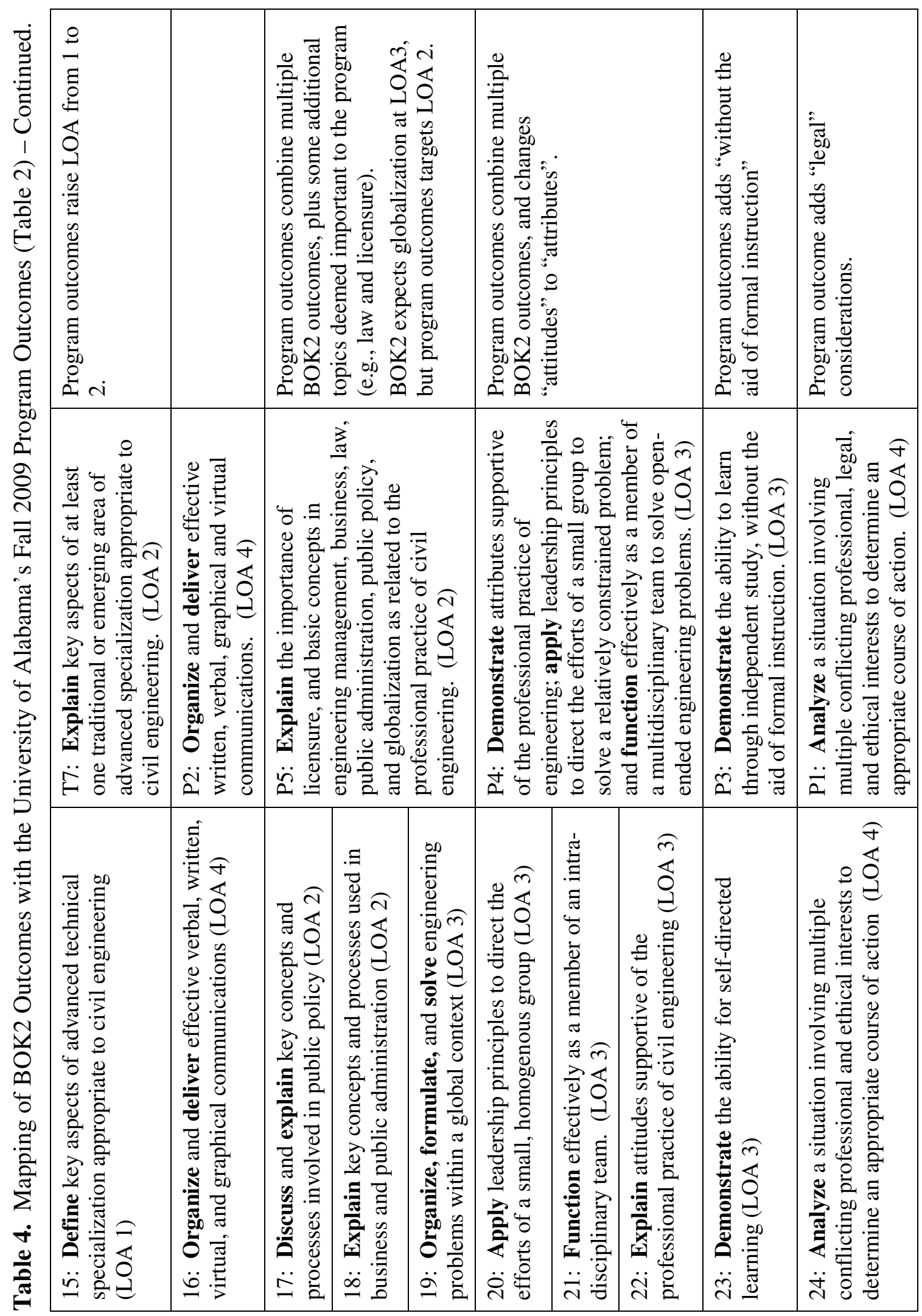




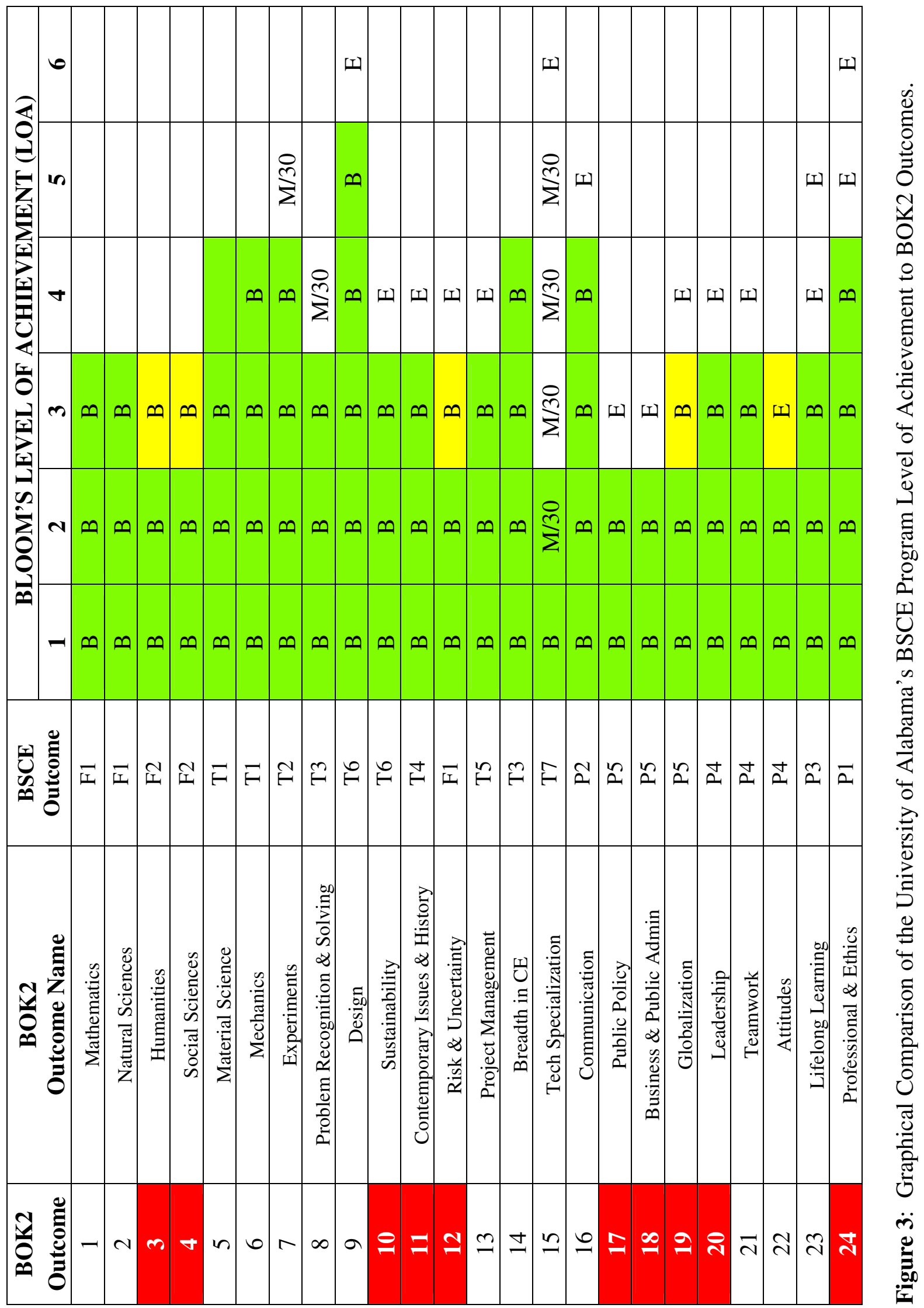




\begin{tabular}{|c|c|c|c|c|c|c|c|c|c|c|c|c|c|c|c|c|c|c|c|c|c|c|c|}
\hline \multirow{14}{*}{ 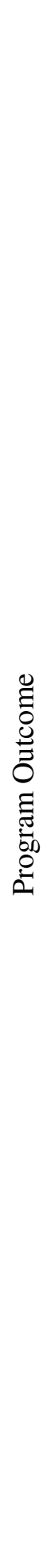 } & $\check{2}$ & $\stackrel{r}{\check{r}}$ & $\begin{array}{l}\infty \\
0\end{array}$ & $\begin{array}{l}\stackrel{0}{0} \\
\stackrel{\sim}{2}\end{array}$ & & $\tilde{\sim}$ & $\begin{array}{c}0 \\
\dot{n}\end{array}$ & in & $\begin{array}{l}0 \\
\dot{\nabla}\end{array}$ & $m$ & $\begin{array}{c}0 \\
\dot{r}\end{array}$ & $\stackrel{0}{i}$ & $\begin{array}{c}0 \\
\dot{r}\end{array}$ & $\begin{array}{c}0 \\
\dot{n}\end{array}$ & $\stackrel{0}{\circ}$ & $\stackrel{0}{i}$ & $\begin{array}{l}0 \\
\text { ले }\end{array}$ & $n$ & $\stackrel{0}{\dot{m}}$ & $m$ & $m$ & $n$ & $\ddot{\circ}$ \\
\hline & $\Xi$ & $\tilde{n}$ & $\grave{0}$ & 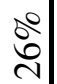 & & $\tilde{\sim}$ & $\begin{array}{c}0 \\
\dot{n}\end{array}$ & $\begin{array}{l}0 \\
\dot{m}\end{array}$ & $\begin{array}{l}0 \\
\dot{\nabla}\end{array}$ & $\begin{array}{l}0 \\
\dot{r}\end{array}$ & $\begin{array}{c}0 \\
\dot{r}\end{array}$ & ஸे. & $\begin{array}{l}0 \\
\dot{f}\end{array}$ & $\begin{array}{c}0 \\
\dot{n}\end{array}$ & $\stackrel{n}{m}$ & $\stackrel{0}{\circ}$ & $\stackrel{0}{\circ}$ & $\begin{array}{l}0 \\
i\end{array}$ & $\begin{array}{c}0 \\
\dot{m}\end{array}$ & $\stackrel{\circ}{\circ}$ & $\begin{array}{l}0 \\
\text { in }\end{array}$ & $n$ & $\stackrel{\circ}{+}$ \\
\hline & $\tilde{\Omega}$ & $\begin{array}{l}\infty \\
\dot{r}\end{array}$ & $\tilde{0}$ & ڤ̊ & & $\stackrel{0}{\circ}$ & $\begin{array}{c}0 \\
\dot{r}\end{array}$ & 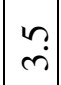 & $\begin{array}{l}0 \\
\dot{\nabla}\end{array}$ & $\hat{r}$ & $\begin{array}{c}0 \\
\dot{m}\end{array}$ & $\dddot{n}$ & $\begin{array}{l}0 \\
\dot{+}\end{array}$ & $\begin{array}{c}0 \\
\dot{n}\end{array}$ & $\stackrel{0}{+}$ & $\begin{array}{l}\circ \\
\dot{\forall}\end{array}$ & $\begin{array}{c}0 \\
\dot{n}\end{array}$ & $\begin{array}{c}0 \\
\dot{r}\end{array} \mid$ & $\begin{array}{c}0 \\
\dot{r}\end{array}$ & $n$ & $\stackrel{\sim}{+}$ & 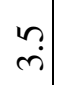 & 우 \\
\hline & $\Sigma$ & $\vec{r}$ & $\hat{0}$ & ڤ̊ & & $\stackrel{0}{\circ}$ & $\begin{array}{l}0 \\
\dot{n}\end{array}$ & $\begin{array}{l}0 \\
\dot{r}\end{array}$ & $\begin{array}{l}0 \\
\dot{\nabla}\end{array}$ & $m$ & $\begin{array}{c}0 \\
\text { ri }\end{array}$ & 官 & $\begin{array}{l}0 \\
\dot{+}\end{array}$ & $\begin{array}{c}0 \\
\dot{n}\end{array}$ & $\stackrel{n}{n}$ & $\begin{array}{l}0 \\
\dot{\forall}\end{array}$ & $\stackrel{\circ}{+}$ & $\begin{array}{l}0 \\
\dot{+}\end{array}$ & $\begin{array}{c}0 \\
\text { r. }\end{array}$ & $n$ & $\stackrel{n}{\forall}$ & $n$ & $\stackrel{\circ}{+}$ \\
\hline & $\bar{a}$ & $m$ & $\hat{0}$ & $\begin{array}{l}\stackrel{0}{2} \\
\text { הి }\end{array}$ & & $\tilde{n}$ & $\begin{array}{c}0 \\
\dot{n}\end{array}$ & $n$ & $\begin{array}{l}0 \\
\dot{+}\end{array}$ & $\hat{r}$ & $\begin{array}{c}0 \\
\dot{m}\end{array}$ & $\stackrel{n}{\forall}$ & $\begin{array}{c}0 \\
\dot{r}\end{array}$ & $\begin{array}{c}0 \\
\dot{m}\end{array}$ & $\begin{array}{c}0 \\
\dot{n}\end{array}$ & $\begin{array}{c}0 \\
\dot{m}\end{array}$ & $\stackrel{\circ}{\mathrm{i}}$ & $\begin{array}{l}n \\
m\end{array}$ & $\begin{array}{c}0 \\
\dot{0}\end{array}$ & $\begin{array}{l}0 \\
\dot{\forall}\end{array}$ & $\stackrel{n}{n}$ & $n$ & $\stackrel{\circ}{\circ}$ \\
\hline & $\hat{F}$ & $\begin{array}{l}0 \\
\dot{m}\end{array}$ & $\hat{0}$ & $\frac{0^{\circ}}{2}$ & & $\underset{\text { ஸे }}{0}$ & $\begin{array}{c}0 \\
i \\
0\end{array}$ & 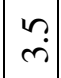 & rn & $m$ & $\begin{array}{c}0 \\
\dot{m}\end{array}$ & 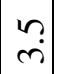 & $\begin{array}{c}0 \\
\dot{n}\end{array} \mid$ & $\begin{array}{l}0 \\
\dot{\forall}\end{array}$ & $\stackrel{\circ}{\forall}$ & $\stackrel{\circ}{i}$ & $\stackrel{\circ}{+}$ & $\begin{array}{l}0 \\
\dot{+}\end{array}$ & $\begin{array}{c}0 \\
\dot{m}\end{array}$ & 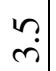 & $\begin{array}{l}\stackrel{0}{+} \\
\dot{f}\end{array}$ & $\stackrel{0}{\dot{m}}$ & $\stackrel{\circ}{\oplus}$ \\
\hline & 6 & $\dot{m}$ & $\begin{array}{l}\infty \\
0\end{array}$ & ๖̊ & & $\stackrel{0}{i}$ & $\begin{array}{l}0 \\
\dot{n}\end{array}$ & $\left|\begin{array}{l}0 \\
\text { ri. }\end{array}\right|$ & $\stackrel{n}{+}$ & $\stackrel{0}{\stackrel{+}{+}}$ & $\vec{m}$ & $\stackrel{n}{m}$ & $\stackrel{0}{\dot{f}}$ & $\left|\begin{array}{c}0 \\
\dot{n}\end{array}\right|$ & $\stackrel{n}{m}$ & $\begin{array}{c}0 \\
\dot{m}\end{array}$ & بे. & $\begin{array}{c}0 \\
\dot{r}\end{array} \mid$ & $\stackrel{0}{\dot{m}}$ & $\stackrel{\circ}{\stackrel{+}{+}}$ & $\stackrel{n}{+}$ & $\stackrel{n}{m}$ & $\stackrel{\circ}{\circ}$ \\
\hline & $n$ & $\dddot{n}$ & $\stackrel{\infty}{0}$ & $\begin{array}{l}\stackrel{0}{2} \\
\text { ते }\end{array}$ & & $\stackrel{0}{\oplus}$ & $\begin{array}{c}0 \\
\dot{n}\end{array}$ & 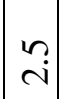 & $\stackrel{n}{+}$ & $m$ & $\begin{array}{c}0 \\
\text { ri }\end{array}$ & $n$ & $\begin{array}{l}0 \\
\dot{\tau}\end{array}$ & $\begin{array}{c}0 \\
i \\
i\end{array}$ & $\stackrel{0}{\dot{m}}$ & $\stackrel{0}{\circ}$ & $\stackrel{\circ}{\mathrm{i}}$ & $\begin{array}{l}0 \\
\dot{+}\end{array}$ & $\begin{array}{c}0 \\
\dot{m}\end{array}$ & $\stackrel{n}{n}$ & 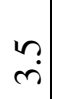 & $\begin{array}{l}0 \\
\dot{f}\end{array}$ & $\stackrel{\circ}{+}$ \\
\hline & $\stackrel{+}{\uplus}$ & $\stackrel{\nabla}{\dot{r}}$ & $\begin{array}{l}\infty \\
0\end{array}$ & 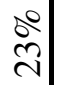 & & $\stackrel{0}{i}$ & $\begin{array}{c}0 \\
\dot{r}\end{array}$ & $\mid \begin{array}{l}0 \\
\dot{m}\end{array}$ & $\because$ & $\tilde{m}$ & $\begin{array}{c}0 \\
\text { r. }\end{array}$ & $n$ & $\begin{array}{l}0 \\
\dot{\sigma}\end{array}$ & $\begin{array}{l}0 \\
\dot{\forall}\end{array}$ & $\begin{array}{l}0 \\
\dot{\forall}\end{array}$ & $\stackrel{0}{i}$ & $\stackrel{0}{\circ}$ & $\begin{array}{c}0 \\
\dot{r}\end{array} \mid$ & $\begin{array}{c}0 \\
\dot{m}\end{array}$ & $n$ & $\stackrel{\circ}{\circ}$ & 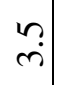 & $\stackrel{\circ}{\circ}$ \\
\hline & 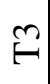 & $\stackrel{\nabla}{\dot{m}}$ & $\begin{array}{l}\infty \\
0\end{array}$ & $\begin{array}{l}\stackrel{0}{0} \\
\stackrel{\sim}{n}\end{array}$ & & $\stackrel{0}{\dot{m}}$ & $\begin{array}{c}0 \\
\dot{r}\end{array}$ & $\begin{array}{l}0 \\
\text { in }\end{array}$ & $\begin{array}{l}0 \\
\dot{+}\end{array}$ & $\tilde{m}$ & $\hat{i}$ & 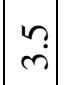 & $\begin{array}{l}0 \\
\dot{+}\end{array}$ & $\begin{array}{l}0 \\
\dot{\forall}\end{array}$ & $\begin{array}{l}0 \\
\dot{\forall}\end{array}$ & $\stackrel{\circ}{i}$ & $\begin{array}{l}0 \\
\text { ले }\end{array}$ & $\begin{array}{l}0 \\
\dot{+}\end{array}$ & $\begin{array}{c}0 \\
\dot{r}\end{array}$ & $\begin{array}{l}0 \\
\dot{\forall}\end{array}$ & $\stackrel{n}{n}$ & $n$ & $\stackrel{0}{\dot{\forall}}$ \\
\hline & $\mathrm{N}$ & $\begin{array}{l}0 \\
\dot{m}\end{array}$ & $\ddot{0}$ & $\begin{array}{l}00 \\
\text { å }\end{array}$ & & ก & $\begin{array}{c}0 \\
\dot{r}\end{array}$ & $\begin{array}{l}0 \\
\dot{r}\end{array}$ & $\begin{array}{l}0 \\
\dot{+}\end{array}$ & $m$ & $\begin{array}{c}0 \\
\dot{r}\end{array}$ & $\begin{array}{l}0 \\
\dot{f}\end{array}$ & $\begin{array}{l}0 \\
\dot{+}\end{array}$ & $\begin{array}{c}0 \\
\dot{m}\end{array}$ & $\begin{array}{l}0 \\
\dot{+}\end{array}$ & $\begin{array}{l}0 \\
\dot{\forall}\end{array}$ & $\stackrel{0}{\oplus}$ & $\ddot{n}$ & $\begin{array}{c}0 \\
\text { ले }\end{array}$ & $\begin{array}{l}0 \\
\dot{\nabla}\end{array}$ & $\stackrel{\circ}{\circ}$ & $\begin{array}{c}0 \\
\dot{m}\end{array}$ & $\begin{array}{c}0 \\
\dot{r}\end{array}$ \\
\hline & $\Xi$ & $\stackrel{+}{\dot{r}}$ & 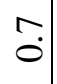 & $\frac{0}{2}$ & & $\stackrel{0}{\circ}$ & $\begin{array}{c}0 \\
\dot{n}\end{array} \mid$ & in & $\begin{array}{l}0 \\
\dot{\nabla}\end{array}$ & $m$ & $\hat{\mathrm{i}}$ & $\tilde{n}$ & $\begin{array}{c}0 \\
\dot{r}\end{array} \mid$ & $\begin{array}{c}0 \\
\dot{m}\end{array}$ & 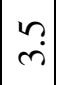 & $\begin{array}{c}0 \\
\dot{m}\end{array}$ & $\stackrel{0}{\circ}$ & $\begin{array}{l}0 \\
\dot{\nabla}\end{array}$ & $\begin{array}{c}0 \\
\dot{r}\end{array}$ & $n$ & $\ddot{n}$ & $n$ & $\begin{array}{c}0 \\
i\end{array}$ \\
\hline & $\sqrt{\mathrm{I}}$ & $\stackrel{\sim}{n}$ & $\stackrel{0}{-}$ & $\begin{array}{l}\stackrel{0}{0} \\
\text { तो }\end{array}$ & & ก & $\begin{array}{c}0 \\
\dot{n}\end{array} \mid$ & 0 & $\begin{array}{l}n \\
\forall\end{array}$ & 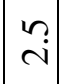 & $\begin{array}{c}0 \\
\dot{r}\end{array} \mid$ & $\begin{array}{l}0 \\
\forall\end{array}$ & $\begin{array}{c}0 \\
\dot{r}\end{array} \mid$ & $\begin{array}{c}0 \\
\dot{m}\end{array}$ & $\mid \begin{array}{l}n \\
m\end{array}$ & $\stackrel{0}{\circ}$ & $\stackrel{\circ}{\mathrm{i}}$ & $\begin{array}{c}0 \\
\dot{m}\end{array} \mid$ & $\stackrel{0}{0}$ & $\stackrel{\circ}{+}$ & $\stackrel{0}{\dot{0}}$ & $\stackrel{n}{\sim}$ & $\begin{array}{c}0 \\
\dot{r}\end{array}$ \\
\hline & $\vec{I}$ & $\stackrel{\nabla}{\dot{r}}$ & $\dot{0}$ & \begin{tabular}{l}
$\stackrel{0}{2}$ \\
\multirow{2}{n}{}
\end{tabular} & & $\stackrel{0}{\circ}$ & $\begin{array}{c}0 \\
\dot{n}\end{array} \mid$ & $\begin{array}{l}0 \\
i\end{array}$ & $\begin{array}{l}n \\
n\end{array}$ & $\vec{r}$ & ñ & ñ & $\begin{array}{l}0 \\
\dot{+}\end{array} \mid$ & $\begin{array}{l}0 \\
\dot{\gamma}\end{array}$ & $\begin{array}{c}0 \\
\dot{m}\end{array}$ & $\stackrel{0}{i}$ & $\stackrel{0}{\oplus}$ & $\begin{array}{c}0 \\
\dot{0}\end{array} \mid$ & $\begin{array}{c}0 \\
\dot{m}\end{array}$ & $\underset{\forall}{0}$ & $n$ & $\begin{array}{c}0 \\
\text { r. }\end{array} \mid$ & $\stackrel{\circ}{\circ}$ \\
\hline & & & છิ & 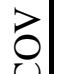 & $\frac{\bar{v}}{\tilde{z}} \theta$ & - & $N$ & $m$ & $\nabla$ & $n$ & 6 & $r$ & $\infty$ & $a$ & 의 & $=$ & $\simeq$ & $m$ & \pm & $n$ & 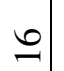 & 그 & $\infty$ \\
\hline
\end{tabular}

